\title{
Research on Plastic Zone Evolution Law of Surrounding Rock of Gob-Side Entry Retaining under Typical Roof Conditions in Deep Mine
}

\author{
Jingke Wu $\mathbb{D}^{1,2,3}$ Yun Dong, ${ }^{1}$ Yang Jiang, ${ }^{1}$ Yushun Yang, ${ }^{1}$ Huasheng Sun, ${ }^{1}$ Deyu Yin, ${ }^{1}$ \\ and Wenhu Gu ${ }^{1}$ \\ ${ }^{1}$ Faculty of Architecture and Civil Engineering, Huaiyin Institute of Technology, Huaian, Jiangsu 223001, China \\ ${ }^{2}$ Jiangsu Baoli International Investment Co., Ltd., Jiangyin, Jiangsu 214400, China \\ ${ }^{3}$ School of Transportation, Southeast University, Nanjing, Jiangsu 211189, China \\ Correspondence should be addressed to Jingke Wu; wujingke@hyit.edu.cn
}

Received 14 September 2020; Revised 25 September 2020; Accepted 1 October 2020; Published 23 October 2020

Academic Editor: Guangchao Zhang

Copyright $\odot 2020$ Jingke Wu et al. This is an open access article distributed under the Creative Commons Attribution License, which permits unrestricted use, distribution, and reproduction in any medium, provided the original work is properly cited.

To solve the control problem of the surrounding rock of gob-side entry retaining under typical roof conditions in deep mines, we conduct theoretical analysis, numerical simulation, and actual measurements. Starting from the plastic zone of the surrounding rock, the serious damage area, the degree and scope of damage, and the dynamic evolution process of the surrounding rock of the gob-side entry retaining are systematically analyzed under four typical roof conditions in deep mines; the expansion and evolution laws of the plastic zone of the surrounding rock are expounded; and a key control technology is proposed. The results indicate that (1) the plastic failure of surrounding rock was concentrated mainly on the coal side and on the floor, especially in the filling body. The plastic zone of the surrounding rock of the gob-side entry retaining with the thick immediate roof was widely distributed and deep, but the plastic failure of the filling body was not obvious. The plastic failure of the surrounding rock of the gob-side entry retaining with the compound roof was mainly concentrated on the roof, filling body, and floor of the filling area. (2) According to the typical roof conditions of the deep gob-side entry retaining, the order of the degree of damage to the surrounding rock was as follows: thick immediate roof, compound roof, thin immediate roof, and thick-hard roof. (3) A "multisupport structure" control system is proposed for the gob-side entry retaining in a deep mine, including measures for enhancing the bearing performance of the anchorage system, increasing the strength of the cataclastic coal-rock mass, enhancing the bearing capacity of the filling body, and increasing the bearing capacity on the tunnel side. The proposed technology was applied to the deep gob-side entry retaining project in the east area of Panyi Mine, and it effectively fulfilled the reuse requirements of gob-side entry retaining in deep mines.

\section{Introduction}

As shallow coal resources are depleted, coal mines will gradually transition to the mining of deep coal resources in China [1-3]. In the complex deep geomechanical environment, the challenges associated with coal mining increase rapidly [4]. With the continued improvement of coalmining science and technology, gob-side entry retaining is being widely used in deep mines. However, the mining mode of gob-side entry retaining inevitably increases the influence of strong mining pressure, severity of mine pressure, and mining stress field, in addition to significantly increasing the peak value of lateral abutment pressure. Furthermore, the construction of large-scale intensive mines increases the cross-sectional size of the roadway, which makes it more difficult to maintain the surrounding rock of the gob-side entry retaining. In recent years, domestic and foreign researchers have extensively studied the failure mechanism of and control technology for the rock surrounding the gobside entry retaining in deep mines by means of field investigations and measurements, theoretical analysis, physical simulation tests, numerical simulations, and various engineering practices [5-8]. 
Ma et al. [9] and Wang et al. [10] proposed that the deformation and failure of the roadway are caused by the formation and development of a plastic zone, and the malignant expansion of this plastic zone is the direct cause of large deformation, loose failure, and support failure of the surrounding rock, in addition to revealing the mechanical expansion mechanism of the plastic zone of the rock surrounding a mining roadway. Many scholars have studied the plastic zone study of the surrounding rock. Liu et al. [11, 12] studied the size, angle, and distribution characteristics of the plastic zone of the rock surrounding the gob-side entry retaining, obtained a variation law of the main stress and expansion characteristics of the plastic zone, and clarified the reasons for asymmetric deformation of the surrounding rock. Xie et al. [13] studied the deviatoric stress and evolution law of the plastic zone of the surrounding rock the gob-side entry retaining under mining conditions and developed a partitioned asymmetric control strategy for the surrounding rock. Jia et al. [14] studied the surrounding rock of a mining roadway and proposed that the increase in the principal stress ratio and large rotation of direction caused butterfly leaf leaning on the roof in the plastic area, leading to roof fall accidents. Yuan et al. [15] analyzed the distribution characteristics of the plastic zone of a weak and broken roadway and studied the degrees of influence of the lateral pressure coefficient, cohesion, and internal friction angle on the plastic zone. Luo et al. [16] revealed the in situ stress characteristics of the Huainan coal mine area and its variation law with lithology based on the in situ stress measurement results obtained using the hydraulic fracturing method in five coal-mining areas in Huainan, in addition to analyzing the stress characteristics of the surrounding rock and the change law of the plastic zone after excavation. Li et al. [17] studied the influence of the distribution characteristics of a butterfly blade plastic zone in a deep gob-side entry roof and revealed the formation mechanism of "low resistance and slight variation" in the butterfly blade plastic zone of a deep roadway along a goaf. Wu et al. [18] analyzed the spatiotemporal evolution law of the plastic zone and stress of the surrounding rock for repeated mining roadway and clarified the dynamic static combination mechanism of changes in the plastic zone of the repeated mining roadway. Meng et al. [19] studied the expansion law of the plastic zone of the surrounding rock for different lithologies and clarified the evolution process from local failure to overall roadway instability. Hadjigeorgiou and Karampinos [20] conducted a numerical simulation to study the influence of a roadway excavation sequence on the plastic zone of the surrounding rock and analyzed the control performance of different bolts on the plastic zone. Wang et al. [21] analyzed the control effect of full-face bolting and shotcreting technology on the surrounding rock of a loose fractured roadway from the perspective of controlling the scope of the plastic zone. Yin et al. [22] derived a formula to determine the radius of the plastic zone of the surrounding rock based on the modified lade criterion and clarified the influence of partial stress, intermediate principal stress, internal friction angle of rock, rock cohesion, and drilling radius on the antireflection radius. To study the stress state and plastic zone range of the surrounding rock of a tunnel wall and the surrounding rock in front of a working face after the excavation of a circular cavern, Wang et al. [23] performed FLAC3D simulation of a circular cavern with various buried depths and revealed the mechanical characteristics after excavation. Karampinos et al. [24] studied the relationship between plastic zone expansion and stress distribution in the surrounding rock of a hard rock roadway based on field measurements. By using the conformal mapping function theory, Lu et al. [25] determined the shape and size of the plastic zone of the surrounding rock of a circular roadway under nonhydrostatic stress; the results indicated that the plastic zone was elliptical, and its long axis was oriented along the direction of the minimum in situ stress. Zareifard and Fahimifar [26] derived the stress and displacement solutions of the surrounding rock of a circular roadway and found that the distribution of the plastic zone under a uniform stress field has a decisive effect on the stability of the surrounding rock of the roadway.

The above analyses indicate that the formation and expansion of the plastic zone are extremely important for stability control of the surrounding rock of the roadway. Generally, the plastic zone of the surrounding rock of a roadway is considered an important index for theoretical analysis, numerical simulation, and engineering test effect inspection or evaluation. However, few studies have focused on the plastic zone of the surrounding rock of a gob-side entry retaining in deep mines. In this paper, the space-time evolution law of the plastic zone of the surrounding rock of a gob-side entry retaining in a deep mine is studied by combining theoretical analysis, numerical simulation, and field measurement. Considering the actual conditions in operational mines, a partition control technology for the surrounding rock of the gob-side entry retaining in a deep well is proposed to solve the challenges that arise due to the continuous development of and changes in surrounding rock failure in various disturbed areas.

\section{Gob-Side Entry Retaining Types under Typical Roof Conditions in Deep Mine}

Based on a field investigation of deep gob-side entry retaining in the east area of the Panyi Mine (depth of $800 \mathrm{~m}$ ), Dingji Mine (depth of $850 \mathrm{~m}$ ), Guqiao Mine (depth of $780 \mathrm{~m}$ ), and Zhuji Mine (depth of $900 \mathrm{~m}$ ), according to the occurrence of coal-rock strata, the types of gob-side entry retaining are roughly classified into four main types based on the roof rock strength, the rock layer thickness, the relative position of the rock strata, and the rock caving morphology: thin immediate roof, thick immediate roof, thick-hard roof, and compound roof; see Table 1 .

Figure 1 shows the structure types of gob-side entry retaining with thin immediate roof, thick immediate roof, thick-hard roof, and composite roof. 
TABLE 1: Classification standard of gob-side entry retaining under typical roof conditions in deep mine.

\begin{tabular}{|c|c|c|c|}
\hline Number & Type & Lithologic & Thickness (m) \\
\hline 1 & $\begin{array}{l}\text { Thin immediate } \\
\text { roof }\end{array}$ & $\begin{array}{l}\text { Shale, mudstone, sandstone, } \\
\text { and so on }\end{array}$ & $0.5-3.0 \mathrm{~m}$ \\
\hline 2 & $\begin{array}{l}\text { Thick immediate } \\
\text { roof }\end{array}$ & $\begin{array}{l}\text { Shale, mudstone sandstone, } \\
\text { and so on }\end{array}$ & $>3.0 \mathrm{~m}$ \\
\hline 3 & Thick-hard roof & $\begin{array}{l}\text { Sandstone, limestone, } \\
\text { glutenite, and so on }\end{array}$ & $>5.0 \mathrm{~m}$ \\
\hline 4 & Compound roof & $\begin{array}{l}\text { Shale, mudstone, siltstone, } \\
\text { and so on }\end{array}$ & $\begin{array}{l}\text { The thickness of a single rock layer is less than the mining height, and there is } \\
\text { no thick-hard rock layer in the range of } 5.0-8.0 \mathrm{~m} \text { and above }\end{array}$ \\
\hline
\end{tabular}

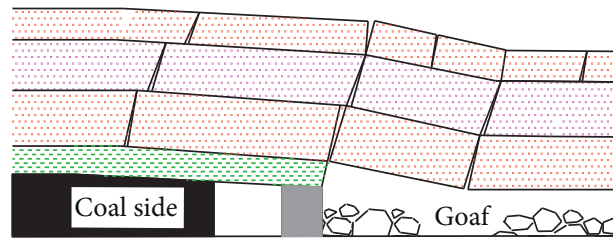

(a)

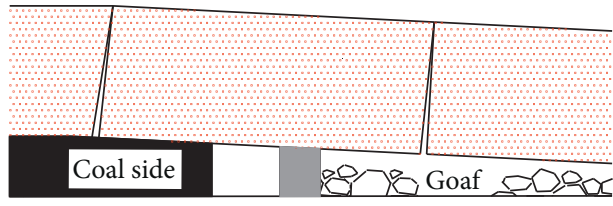

(c)

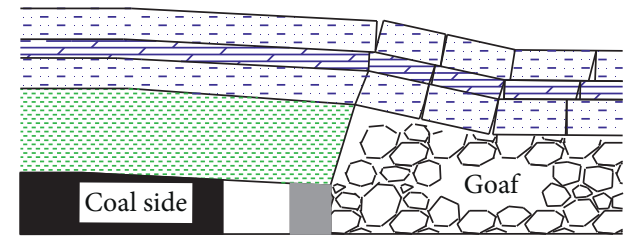

(b)

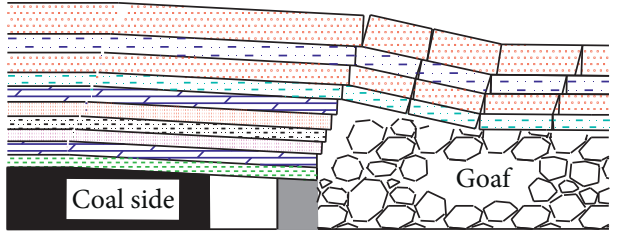

(d)

FIGURE 1: Gob-side entry retaining types under typical roof conditions in deep mine. (a) Gob-side entry retaining with thin immediate roof, (b) gob-side entry retaining with thick immediate roof, (c) gob-side entry retaining with thick-hard roof, and (d) gob-side entry retaining with compound roof.

\section{Plastic Zone Expansion and Evolution of Gob- Side Entry Retaining under Typical Roof Conditions in Deep Mine}

The plastic zone size is an important basis for evaluation of the stability of the surrounding rock. Control of the surrounding rock in the roadway aims to stabilize the plastic zone to avoid malignant expansion and roof fall. Next, a numerical simulation method is used to systematically analyze the area with serious damage, degree of damage, scope of damage, and dynamic evolution process of the deep gobside entry retaining under typical roof conditions; to clarify the expansion and evolution laws of the plastic zone of its surrounding rock; and to determine the key parts that affect the stability of the surrounding rock.

3.1. Construction of Numerical Model. To reveal the failure mechanism of the deep gob-side entry retaining under typical roof conditions, UDEC v.6.0, a discrete element analysis software application, was used to establish a numerical analysis model based on four typical roof conditions, as shown in Figure 2. The dimensions of the model were $120 \mathrm{~m}$ (width) $\times 60 \mathrm{~m}$. The coal seam, roof, and floor were divided into blocks measuring $0.5 \mathrm{~m} \times 0.5 \mathrm{~m}$. The bottom boundary of the model was fixed vertically, and the left and right boundaries were fixed horizontally. The boundary stress of 19.6 MPa was applied to the upper boundary of the model, and the lateral pressure coefficient was set to 1.5. Material constitutive model: the strain-softening model was used for the coal seam, roof, and floor; the Mohr-Coulomb model was used for the rest; and the Coulomb slip model was used as the joint model.

Considering the geological conditions of the working face in the east area of the Panyi Mine, four sets of simulation schemes were developed. Scheme one represented the deep gob-side entry retaining with a thin immediate roof, with an immediate roof thickness of $2 \mathrm{~m}$ and main roof thickness of $5 \mathrm{~m}$. Scheme two represented the deep gob-side entry retaining with a thick immediate roof, and the immediate roof thickness was $8 \mathrm{~m}$. Scheme three represented the deep gob-side entry retaining with a thick-hard roof, and the hard roof thickness was $8 \mathrm{~m}$. Scheme four represented the deep gob-side entry retaining with the compound roof, where the designed thickness of each rock layer was the same, and the average thickness was $1 \mathrm{~m}$. The coal seam and floor conditions in the four schemes were identical. The specific mechanical parameters of the coal seam are listed in Tables 2 and 3. The width and height of the designed section size for the deep gob-side entry retaining were $4.2 \mathrm{~m}$ and $3.2 \mathrm{~m}$, respectively, and the design width of the filling body was $3.0 \mathrm{~m}$. Based on an analysis and research conducted using 


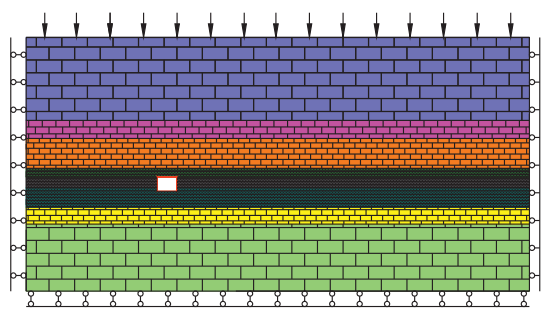

(a)

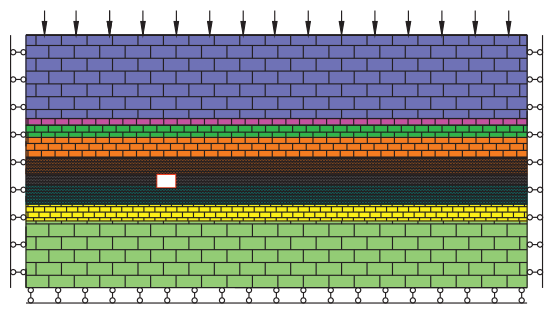

(c)

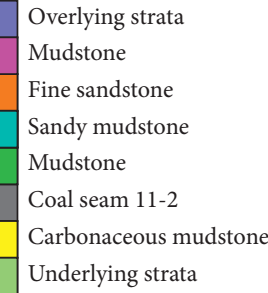

Underlying strata

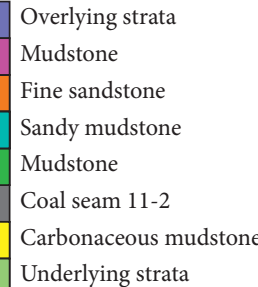

Underlying strata

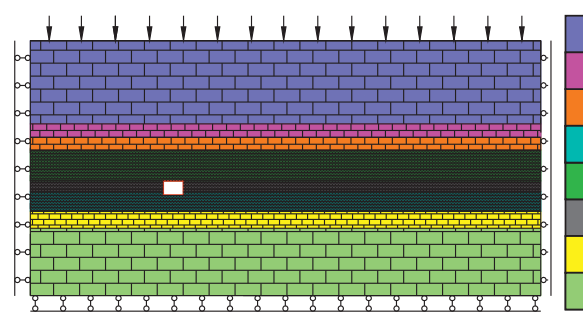

Overlying strata

Mudstone

Fine sandstone

Sandy mudstone

Mudstone

Coal seam 11-2

Carbonaceous mudstone

Underlying strata

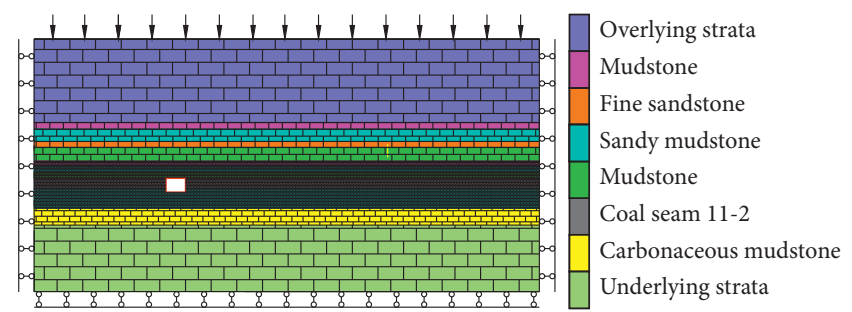

(d)

Figure 2: Numerical analysis model of deep gob-side entry retaining with typical roof conditions. (a) Numerical model 1-gob-side entry retaining with thin immediate roof, (b) numerical model 2-gob-side entry retaining with thick immediate roof, (c) numerical model 3-gobside entry retaining with thick-hard roof, and (d) numerical model 4-gob-side entry retaining with the compound roof.

TABLE 2: Rock mass mechanical properties.

\begin{tabular}{|c|c|c|c|c|c|c|c|}
\hline Stratum name & Density $\left(\mathrm{kg} \cdot \mathrm{m}^{-3}\right)$ & $\begin{array}{l}\text { Bulk modulus } \\
\qquad(\mathrm{GPa})\end{array}$ & $\begin{array}{c}\text { Shear } \\
\text { modulus } \\
(\mathrm{GPa})\end{array}$ & $\begin{array}{c}\text { Cohesion } \\
\text { (MPa) }\end{array}$ & $\begin{array}{l}\text { Tensile } \\
\text { strength } \\
(\mathrm{MPa})\end{array}$ & $\begin{array}{c}\text { Internal } \\
\text { friction angle } \\
\left({ }^{\circ}\right)\end{array}$ & $\begin{array}{c}\text { Dilatancyangle } \\
\left(\left(^{\circ}\right)\right.\end{array}$ \\
\hline Overlying strata & 2700 & 10.6 & 6.30 & 3.90 & 2.50 & 35 & 3 \\
\hline Fine sandstone & 2724 & 7.87 & 3.38 & 3.26 & 2.19 & 28 & 3 \\
\hline Siltstone & 2696 & 8.82 & 4.84 & 3.30 & 2.47 & 30 & 3 \\
\hline Sandy mudstone & 2702 & 3.68 & 2.10 & 2.10 & 1.50 & 25 & 2 \\
\hline Mudstone & 2678 & 3.35 & 2.10 & 1.80 & 1.60 & 24 & 2 \\
\hline Coal seam 11-2 & 1350 & 2.35 & 1.47 & 1.50 & 1.10 & 20 & 2 \\
\hline Mudstone & 2781 & 2.65 & 2.20 & 1.90 & 1.46 & 34 & 2 \\
\hline $\begin{array}{l}\text { Carbonaceous } \\
\text { mudstone }\end{array}$ & 2762 & 2.12 & 1.80 & 2.18 & 2.36 & 28 & 3 \\
\hline Underlying strata & 2732 & 9.91 & 4.92 & 3.26 & 2.19 & 30 & 3 \\
\hline Filling body & 2680 & 6.87 & 3.30 & 3.16 & 2.19 & 28 & 3 \\
\hline
\end{tabular}

TABLE 3: Joints mechanical parameters.

\begin{tabular}{|c|c|c|c|c|c|c|}
\hline Stratum name & $\begin{array}{c}\text { Normal stiffness } \\
(\mathrm{GPa})\end{array}$ & $\begin{array}{c}\text { Tangential stiffness } \\
(\mathrm{GPa})\end{array}$ & $\begin{array}{c}\text { Cohesion } \\
(\mathrm{MPa})\end{array}$ & $\begin{array}{c}\text { Tensile strength } \\
(\mathrm{MPa})\end{array}$ & $\begin{array}{c}\text { Internal friction } \\
\text { angle }\left({ }^{\circ}\right)\end{array}$ & $\begin{array}{c}\text { Dilatancy angle } \\
\left({ }^{\circ}\right) \\
\end{array}$ \\
\hline Overlying strata & 5.3 & 2.50 & 1.9 & 0.50 & 25 & 2 \\
\hline Fine sandstone & 5.2 & 2.38 & 1.26 & 0.39 & 18 & 2 \\
\hline Siltstone & 5.1 & 2.40 & 1.30 & 0.47 & 20 & 2 \\
\hline Sandy mudstone & 2.6 & 1.70 & 1.20 & 0.5 & 15 & 1 \\
\hline Mudstone & 2.5 & 1.50 & 1.36 & 0.39 & 18 & 2 \\
\hline Coal seam 11-2 & 2.0 & 1.30 & 1.10 & 0.10 & 10 & 1 \\
\hline Mudstone & 2.7 & 1.30 & 1.21 & 0.50 & 15 & 1 \\
\hline $\begin{array}{l}\text { Carbonaceous } \\
\text { mudstone }\end{array}$ & 2.3 & 1.40 & 1.30 & 0.60 & 14 & 1 \\
\hline Underlying strata & 5.4 & 2.50 & 1.76 & 0.50 & 20 & 2 \\
\hline
\end{tabular}

the proposed numerical model, the strata pressure behavior characteristics of the gob-side entry retaining in a deep mine under typical roof conditions were determined.
3.2. Evolution Process Analysis of Plastic Zone of Surrounding Rock. Based on the above research, we analyzed the following aspects based on the plastic zone expansion law of the 
surrounding rock to identify the area in the surrounding rock with serious damage and the degree and scope of such damage (Figures 3-6).

(1) Scheme 1. Evolution characteristics of the plastic zone of the surrounding rock of gob-side entry retaining under a thin immediate roof.

Figures 3(a)-3(f) show that as the working face advances, the thin immediate roof in the goaf collapses due to mining, and the overlying rock activities of the gob-side entry retaining that lag behind the lateral edge of the working face gradually become violent. As a result, the roof above the filling body first undergoes shear sliding failure and tensile failure and then flows into the goaf due to plastic extrusion. Second, plastic failure occurs in the shallow coal mass of the solid coal side and the sandy mudstone in the shallow part of the roadway floor (especially under the filling body). Third, the plastic zone of the roof develops from the right to the left, the plastic zone of the coal side extends from the surface to the inside and from the roof to the floor, and the plastic zone of the floor develops from shallow to deep and from the right to left. Plastic failure then develops inside the backfill from bottom to top and from right to left and runs through the entire wall. Finally, the shallow and deep plastic zones of the slope bottom are connected successively.

The main distribution characteristics of the plastic zone in the surrounding rock of the gob-side entry retaining with the thin immediate roof were as follows: (1) The plastic failure zone of the floor and solid coal sides expanded to $2.5-3.5 \mathrm{~m}$ or more. (2) The plastic zone near the goaf edge above the filling body was relatively concentrated. (3) The plastic damage area of the filling body was large. (4) The plastic damage area on the roof was small. Overall, the shear plastic failure and tensile plastic failure zones of the surrounding rock were mainly distributed at the goaf edge, in the coal-rock mass on the solid coal side, and in the sandy mudstone on the floor, and they exhibited an obvious asymmetric state. These findings were consistent with the serious deformation and failure of the gob-side entry retaining with the thin immediate roof.

(2) Scheme 2. Evolution characteristics of the plastic zone in the surrounding rock of the gob-side entry retaining with a thick immediate roof.

Figures $4(\mathrm{a})-4(\mathrm{f})$ show that as the working face advances, the immediate roof of the goaf collapses over a large area, and sporadic plastic damage occurs on the roadway roof on the side of the stope; the plastic damage area on the floor is larger than that on the roof. After 4000 calculation steps, plastic damage occurred in the shallow and deep parts of the roadway roof, and the solid coal side and floor plastic area gradually increased and crossed each other. After 6000 calculation steps, two parallel narrow strips were formed in the roof plastic zone, and the coal side and floor plastic zone overlapped and interweaved. After 8000 calculation steps, the plastic zone of the roof of the filling body gradually expanded, and the two plastic zones of the roof extended to the roof above the solid coal side. After 10,000 calculation steps, the entire roof above the filling body underwent plastic failure, and the plastic zones of roof, coal side, and floor are connected for the first time. After 12,000 calculation steps, the roof was completely covered with the plastic zone and was completely connected to the coal side and the floor, and the floor of the filling body underwent smallarea plastic failure.

The distribution of the plastic zone in the surrounding rock of the deep gob-side entry retaining with the thick immediate roof exhibited the following characteristics: (1) The plastic failure zone of the thick soft roof occurred over a broad range $(>5.0 \mathrm{~m})$, where two parallel plastic zones appeared on the roof above the solid coal side, and the plastic zone fully covered the roadway roof and the roof above the filling body, which is the most serious. (2) The plastic zone of the solid coal side developed in a semiarc state and ran through the plastic zone of the floor. (3) The plastic failure zone of the backfill was located mainly on the outer side, and its range was small and not obvious. Overall, the shear plastic failure zone and the tensile plastic failure zone in the surrounding rock of the gob-side entry retaining with the thick immediate roof ran through the entire area of the surrounding rock, leading to internal inducement of large deformation of the surrounding rock under the thick soft rock condition.

(3) Scheme 3. Evolution characteristics of the plastic zone in the surrounding rock of the deep gob-side entry retaining with a thick-hard roof.

Figures 5(a)-5(f) show that as the working face advances, plastic failure occurs first on the solid coal side and the floor of the gob-side entry retaining with the thick-hard roof, whereas only sporadic plastic failure points appear on the roof. After $6000 \mathrm{cal}-$ culation steps, a plastic failure band appeared on the roof outside the filling body and the roof above the solid coal, but few plastic failure points were observed on the roadway roof. After 10,000 calculation steps, a narrow plastic failure zone was formed between the filling body and the roof shoulder angle in the roadway, plastic zones in the roof above the solid coal were visible and parallel to each other, plastic zones of the coal side and floor were connected, and damage to the filling body was initialized. After 12,000 calculation steps, the entire filling body 


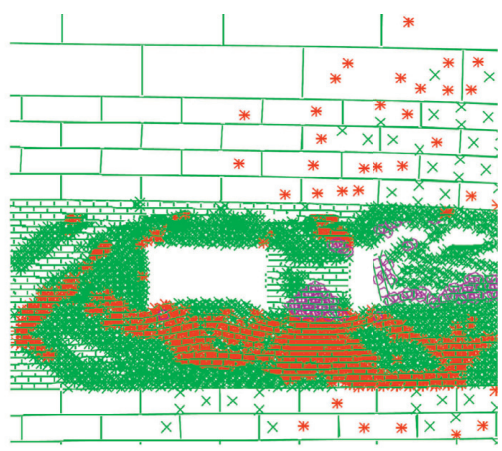

(a)

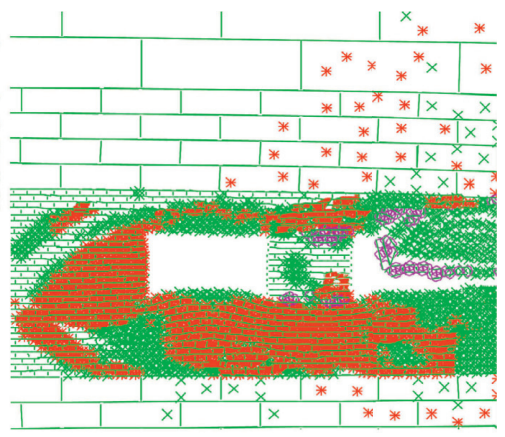

(d)

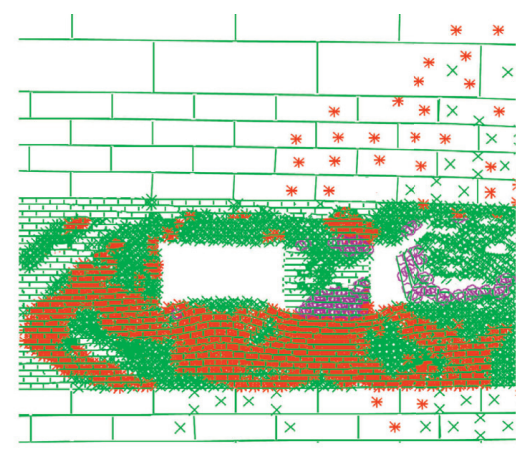

(b)

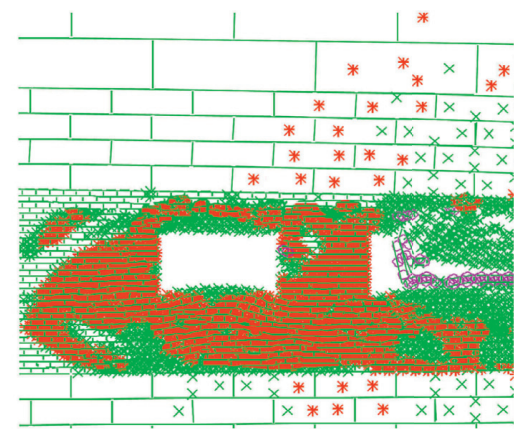

(e)

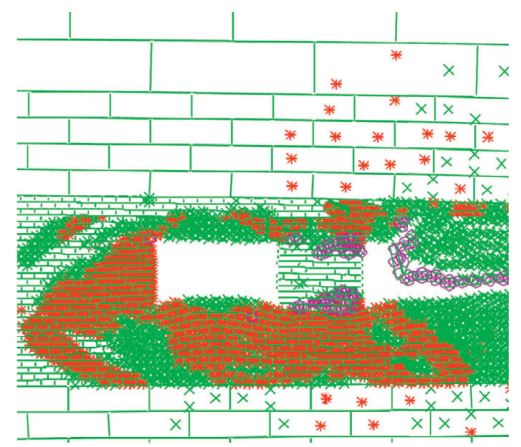

(c)

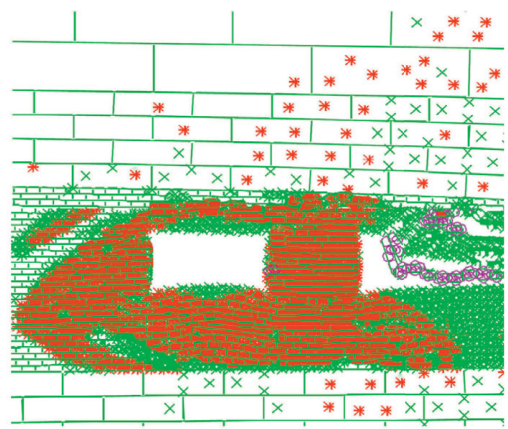

(f)

FIgURE 3: Plastic zone evolution process of deep gob-side entry retaining with thin immediate roof. (a) 2000 steps, (b) 4000 steps, (c) 6000 steps, (d) 8000 steps, (e) 10,000 steps, and (f) 12,000 steps.

underwent plastic failure and expansion deformation under a high-stress state.

The distribution of the plastic zone in the surrounding rock of the deep gob-side entry retaining with the thick-hard roof exhibited the following main characteristics: (1) The plastic failure area of the thick-hard roof was small, and plastic failure was distributed only in a narrow range above the filling body. (2) The plastic failure ranges of the solid coal side and the floor were large, and they were connected to each other, especially in the case of the roadway floor and the floor under the filling body, at depths of 3-4.5 m. (3) The entire filling body underwent plastic fracture and exhibited a state of expansion deformation state. Overall, the shear plastic failure zone and the tensile plastic failure zone in the surrounding rock were mainly distributed in the filling body, solid coal side, and sandy mudstone floor, which was consistent with the serious deformation and failure area of the surrounding rock under the thick-hard roof condition.

(4) Scheme 4. Evolution characteristics of the plastic zone of the surrounding rock of the deep gob-side entry retaining with a compound roof.

Figures 6(a)-6(f) show that the immediate roof of the goaf collapses as the working face advances. After 2000 calculation steps, shear slip failure and tensile failure occurred on the roof and floor near the edge of the goaf. The plastic zone of the roof was located directly above both sides of the filling body, and the plastic zone of the floor was mainly located under the filling body, and it was larger than those on the roof and the coal side. With the continuous advance of the working face, after 4000 calculation steps, the plastic area in each part of the surrounding rock gradually increased, and the plastic zone above the filling body was connected to the plastic zone in the roof of the roadway. After 6000 calculation steps, the bottom corner of the filling body was also deformed, which indicated that the load was large. After 10,000 calculation steps, the plastic areas of roof, side, and floor begin to cross each other, and the plastic zone in the floor corner of the filling body clearly expanded. After 12,000 calculation steps, the filling body and its roof and floor were completely covered with the plastic zone, and the plastic zone of the surrounding rock was connected as a whole. The load acting on the roadside support body of the deep gobside entry retaining with the compound roof was large, which indicated the need to further improve the bearing strength of the filling body.

The distribution of plastic zone in the surrounding rock of the gob-side entry retaining with the composite roof mainly exhibited the following characteristics: (1) The plastic deformation failure zones of the roofs of the roadway and the solid coal side were small and independent. (2) The plastic damage to the bearing structure adjacent to the roadway was 


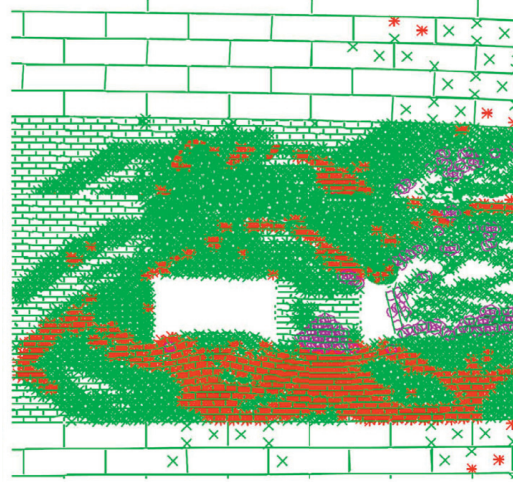

(a)

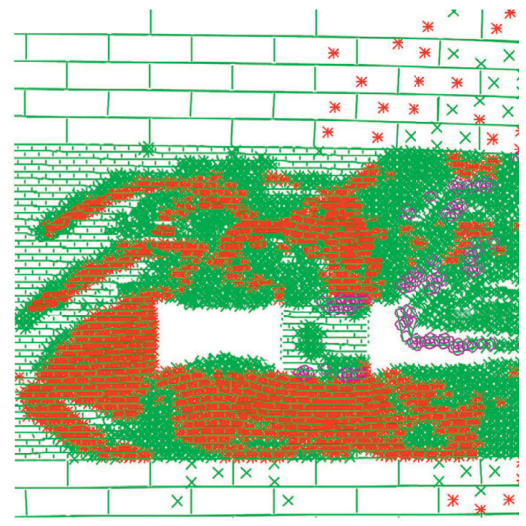

(d)

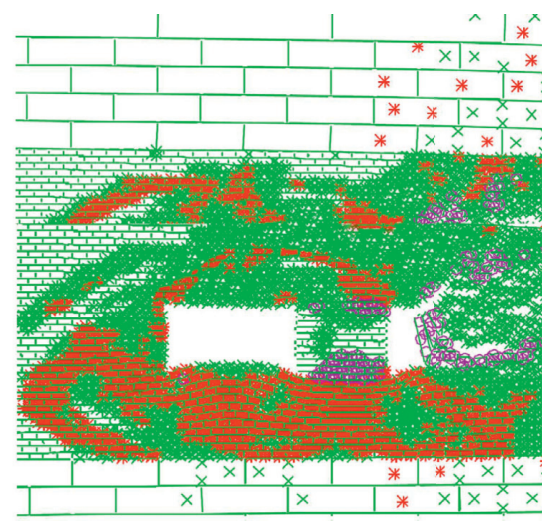

(b)

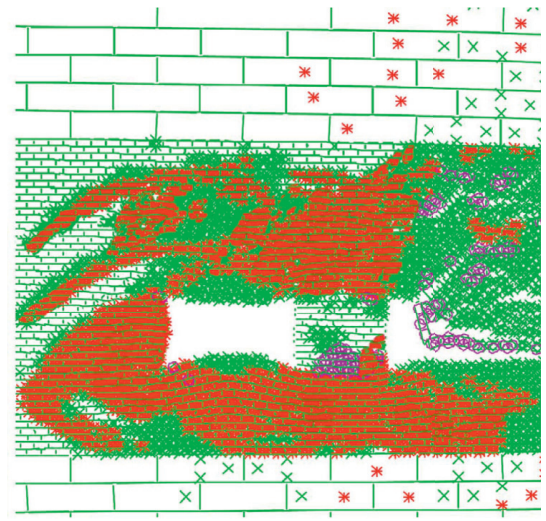

(e)

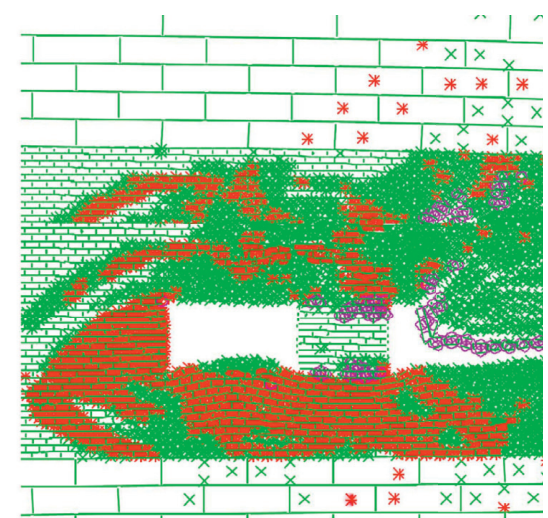

(c)

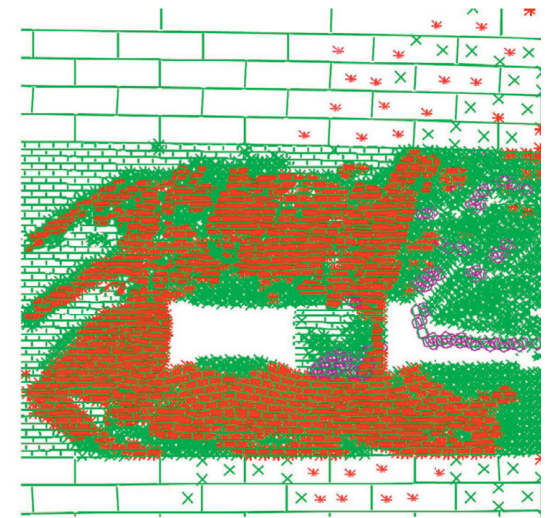

(f)

Figure 4: Plastic zone evolution process of deep gob-side entry retaining with thick immediate roof. (a) 2000 steps, (b) 4000 steps, (c) 6000 steps, (d) 8000 steps, (e) 10,000 steps, and (f) 12,000 steps.

serious, especially that to the filling body and its roof. (3) The plastic failure zone in the floor was mainly concentrated under the filling body and on the floor in the roadway. Overall, the shear plastic failure zone and tensile plastic failure zone of the surrounding rock of the gob-side entry retaining with the compound roof were mainly distributed in the interior of the immediate roof and filling body and on the floor at the edge of the goaf.

Based on the four typical roof conditions, our analysis of the plastic zone of the surrounding rock of the gobside entry retaining in a deep well was concluded as follows: (1) The plastic failure of the surrounding rock of the deep gob-side entry retaining with the thin immediate roof was mainly concentrated on the coal side and floor. In particular, the filling body was heavily loaded and underwent severe plastic damage, whereas the roof exhibited only dense plastic failure points with no obvious changes. (2) In the deep gobside entry retaining with the thick immediate roof, the plastic zone was deeply and widely distributed, and the surrounding rock was severely deformed. The key failure parts of the surrounding rock may have caused overall deformation of the surrounding rock, but the high-strength filling body was in the soft rock stratum with fast unloading speed, and therefore, its plastic failure was not obvious. (3) The plastic failure zone of the deep gob-side entry retaining with the thick-hard roof was similar to that of thin immediate roof. (4) The plastic failure of the surrounding rock of the deep gob-side entry retaining with the compound roof was mainly concentrated on the roadway side. Generally, the damage range and severity of plastic deformation of the surrounding rock of the deep gob-side entry retaining under the four typical roof conditions considered in this study can be arranged in the following decreasing order: gob-side entry retaining with the thick immediate roof, gob-side entry retaining with the compound roof, gob-side entry retaining with the thin immediate roof, and gob-side entry retaining with the thick-hard roof.

\section{Guiding Application of Surrounding Rock Plastic Zone in Support}

4.1. Supporting Principle. It is very important to master the formation and development law of the plastic zone in the surrounding rock of the roadway. Based on the plastic zone theory, design of the surrounding rock support for 


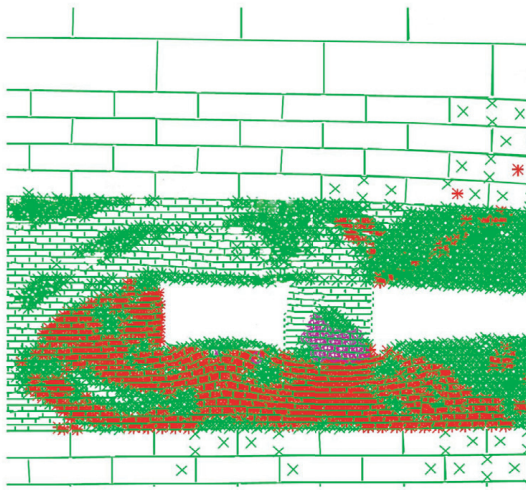

(a)

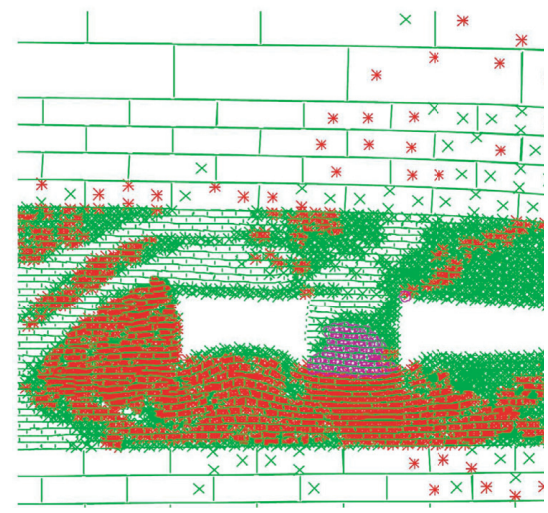

(d)

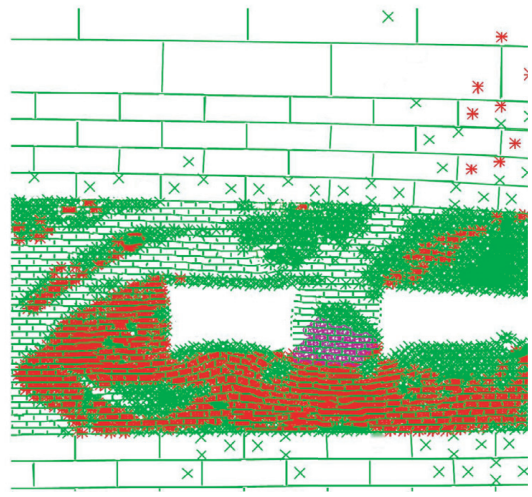

(b)

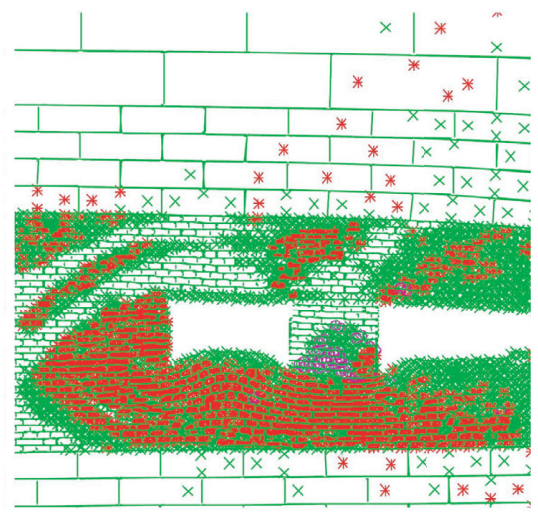

(e)

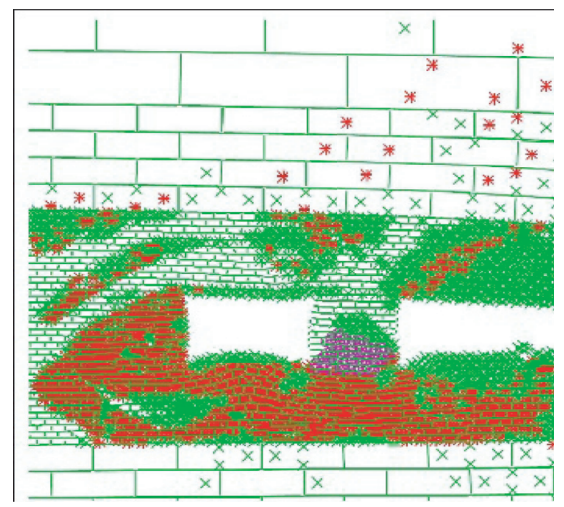

(c)

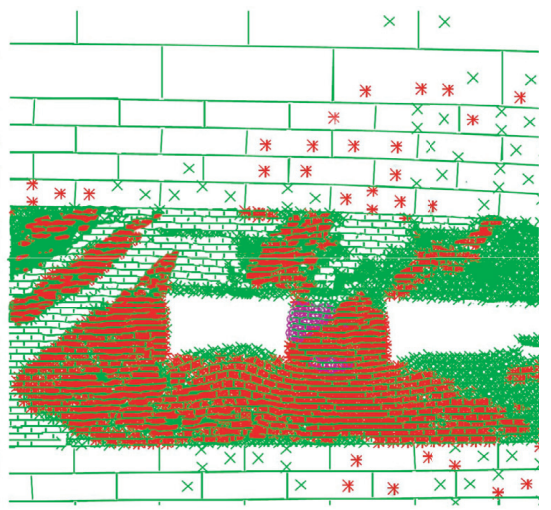

(f)

Figure 5: Plastic zone evolution process of deep gob-side entry retaining with thick-hard roof. (a) 2000 steps, (b) 4000 steps, (c) 6000 steps, (d) 8000 steps, (e) 10,000 steps, and (f) 12,000 steps.

the gob-side entry retaining in a deep mine should be based on the following principles:

(1) There are different designs of support schemes for different areas of the surrounding rock. The gob-side entry retaining in a deep mine is acted upon by a nonuniform pressure stress field. In different stages of the excavation process, the boundary depth of the plastic zone varies in different parts of the surrounding rock. The support scheme should be designed according to the depth of the plastic zone in different parts of the surrounding rock, especially the length of bolt (cable), to ensure that the anchorage foundation of each part is located in the stable elastic zone outside the plastic zone to not only reduce excess support but also avoid scenarios in which the support has insufficient strength.

(2) Determine the key supporting parts. One should grasp the shape characteristics, scope, and expansion direction of the plastic zone of the surrounding rock; determine the key area that can easily cause failure or even collapse of the surrounding rock; and set it as the key support position to avoid the influence of plastic zone expansion on the anchorage foundation during the service period.
(3) Improving the residual strength of the surrounding rock surface and controlling its crushing and swelling deformation are effective measures to control the expansion of the plastic zone of the surrounding rock. After roadway excavation, the bolt (cable) support should be installed in time, and a high preload should be applied to enhance the active support function of the bolt (cable), improve the residual strength of the surrounding fractured rock surface, control its crushing expansion deformation, and achieve the purpose of indirectly controlling the expansion rate of the plastic zone to the surrounding rock.

\subsection{Engineering Application}

4.2.1. Project Overview. The number 1221 (1) working face is located near the turning end of the anticline in Panyi district. The structural geological conditions at this face are generally simple, and the buried depth exceeds $800 \mathrm{~m}$. The attitude of coal-rock formation is $90-130^{\circ}<1-8^{\circ}$, and this formation belongs to the coal-bearing rock series of the upper Shihezi Formation of the Permian system; the main lithology is sandstone and mudstone. The main mining coal seam number 11-2 is relatively stable, and the distribution of coal seams is shown in Figure 7. This is a dangerous area, with a 


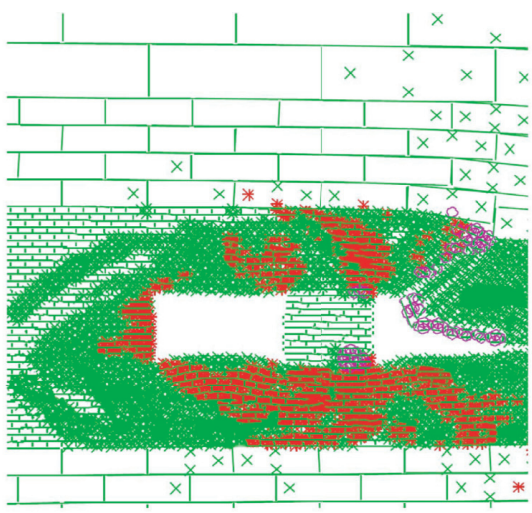

(a)

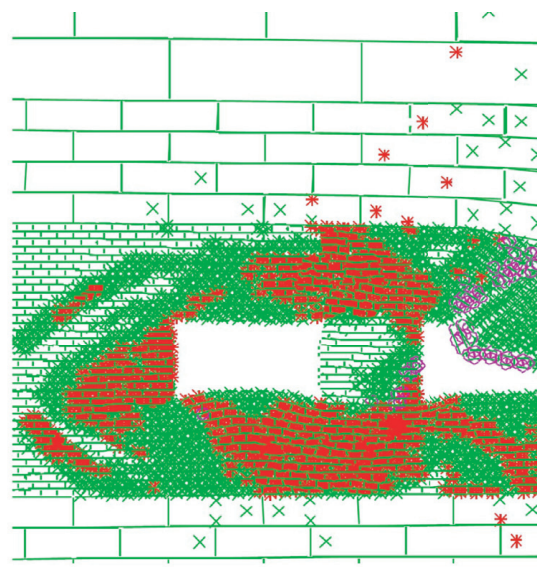

(d)

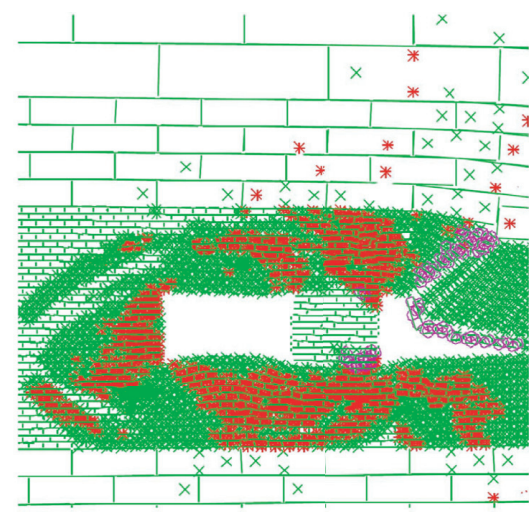

(b)

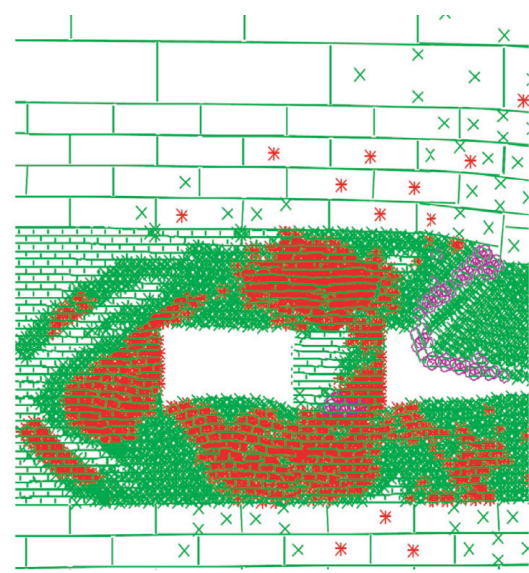

(e)

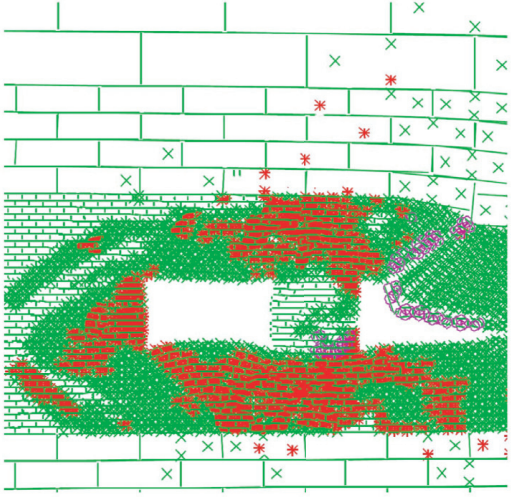

(c)

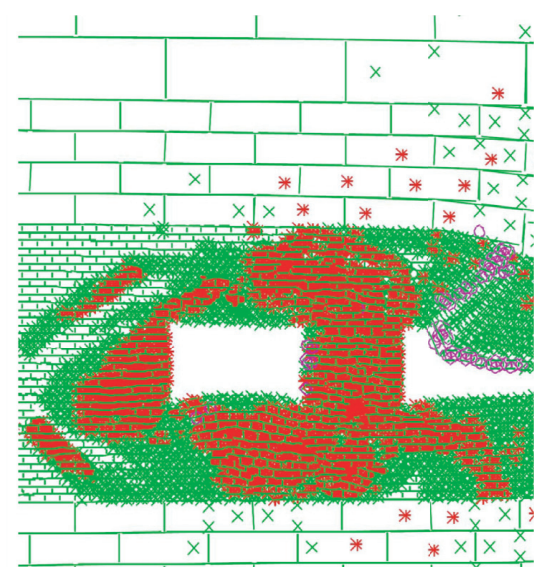

(f)

Figure 6: Plastic zone evolution process of deep gob-side entry retaining with compound roof. (a) 2000 steps, (b) 4000 steps, (c) 6000 steps, (d) 8000 steps, (e) 10,000 steps, and (f) 12,000 steps.

gas emission of $10.08 \mathrm{~m}^{3} / \mathrm{t}$ and simple hydrogeological conditions. The strike length of the working face is $1293 \mathrm{~m}$, the slope length is $245 \mathrm{~m}$, and the design section dimensions of the section track roadway are $5 \mathrm{~m}$ (width) $\times 3.2 \mathrm{~m}$ (height). During mining, the semi-in situ method of gobside entry retaining was adopted in the section track roadway, and the design section size was $4.2 \mathrm{~m} \times 3.2 \mathrm{~m}$.

4.2.2. Technical Scheme for Surrounding Rock Control. According to the engineering geological conditions of the number 1221 (1) working face, the gob-side entry retaining is under the typical thick-hard roof direct overburden condition. Based on the expansion and evolution laws of the plastic zone of the surrounding rock under this condition, the "multisupport structure" control technology was adopted, as shown in Figure 8.

The specific support parameters of the surrounding rock before and after the deep gob-side entry retaining with the thick-hard roof are shown in Figure 9.

(1) Specific Support Parameters of Section Track Roadway. Roof support: each row was equipped with six $\Phi 22 \mathrm{~mm} \times 2500 \mathrm{~mm}$ bolts and an L4800 $\mathrm{mm}$ M5 steel strip, and the spacing and row spacing were
$900 \mathrm{~mm} \times 800 \mathrm{~mm}$. We used a $\Phi 22 \mathrm{~mm} \times 7300 \mathrm{~mm} /$ $6300 \mathrm{~mm}$ anchor cable with $14 \#$ channel steel of $\mathrm{L} 2600 \mathrm{~mm}$, and three holes in one beam were arranged vertically in the 3-3 mode. A hollow grouting anchor cable with a diameter of $\Phi 22 \mathrm{~mm} \times \mathrm{L} 6300 \mathrm{~mm}$ was arranged at both ends of the channel steel beam with an external angle of $15^{\circ}$, and the spacing and row spacing for all anchor cables were $1200 \mathrm{~mm} \times 800 \mathrm{~mm}$. A 10 \# galvanized iron wire was used to mechanically weave a $5600 \mathrm{~mm} \times 1000 \mathrm{~mm}$ rhombic mesh.

Coal-Side Support Parameters. Each vertical row was equipped with five $\Phi 22 \mathrm{~mm} \times 2500 \mathrm{~mm}$ bolts and an L1800 mm M5 steel strip, and the spacing and row spacing were set to $725 \mathrm{~mm} \times 800 \mathrm{~mm}$. Three anchor cable beams were arranged along the roadway trend by using $\Phi 22 \mathrm{~mm} \times 7300 \mathrm{~mm} / 6300 \mathrm{~mm}$ anchor cables and 14\# channel steel of L3200 mm, with three holes in one beam and the spacing and row spacing of $1000 \mathrm{~mm} \times 800 \mathrm{~mm}$, to strengthen the deep support of the coal side. Moreover, 10\# galvanized iron wire was used to mechanically weave a $3400 \mathrm{~mm} \times 1000 \mathrm{~mm}$ rhombic mesh. 


\begin{tabular}{|c|c|c|}
\hline Histogram & Stratum name & Thickness (m) \\
\hline $\begin{array}{ll}------1 \\
------1\end{array}$ & Fine sandstone & $\frac{0.1 \sim 1.3}{0.6}$ \\
\hline 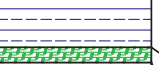 & Mudstone & $\frac{0.3 \sim 4.2}{2.0}$ \\
\hline 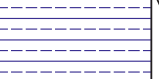 & Carbonaceous mudstone & $\begin{array}{c}0 \sim 0.6 \\
0.3\end{array}$ \\
\hline 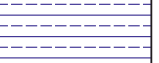 & Mudstone & $\frac{1.5 \sim 7.2}{4.7}$ \\
\hline 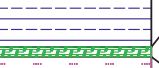 & Carbonaceous mudstone & $\frac{0 \sim 0.3}{0.2}$ \\
\hline & Siltstone & $\frac{2.6 \sim 6.3}{5.1}$ \\
\hline \multirow{3}{*}{ 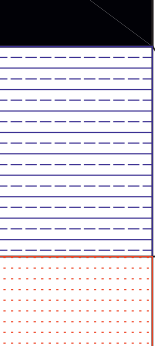 } & Coal seam 11-2 & $\frac{0.7 \sim 3.4}{2.3}$ \\
\hline & Mudstone & $\frac{1.6 \sim 7.9}{4.2}$ \\
\hline & Fine sandstone & $\frac{0 \sim 4.1}{2.5}$ \\
\hline
\end{tabular}

FIgURE 7: Histogram of coal and rock strata in 1221 (1) working face.

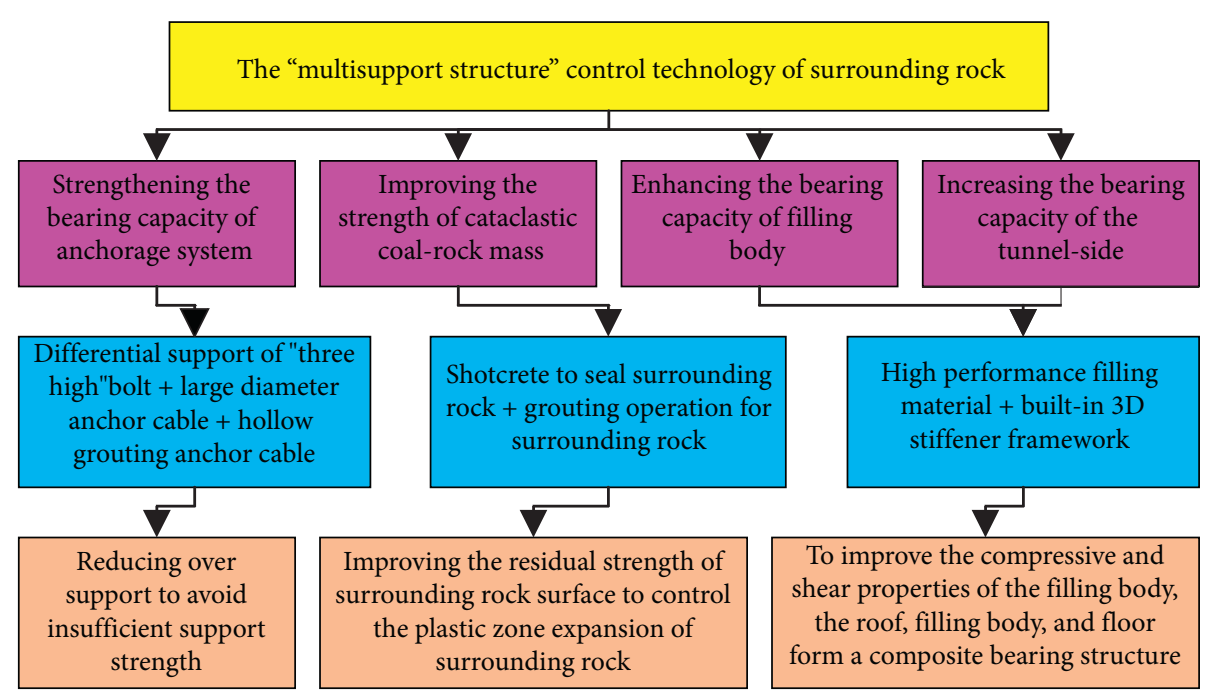

FIGURE 8: "Multisupport structure" control technology of deep gob-side entry retaining with thick-hard roof.

(2) Reinforcement Parameters of Surrounding Rock before Gob-Side Entry Retaining. It is necessary to spray concrete to seal the surrounding rock. In this study, the thickness of the shotcrete layer was 70-100 mm, and its strength was C20. A grouting operation was carried out on the roof and on the coal side to strengthen the surrounding rock. To this end, highgrade $425 \#$ cement was used, and the slurry water: cement ratio was $1: 2$, final grouting hole pressure was 6-7 MPa, and the pressure stabilizing time was 3-5 $\mathrm{min}$.

(3) Gap Roof Reinforcement Parameters at the End of the Working Face. Each row was equipped with four $\Phi 22 \mathrm{~mm} \times \mathrm{L} 2500 \mathrm{~mm}$ bolts and an M5 steel strip with a pretightening force of $60-80 \mathrm{kN}$, and the spacing and row spacing were set to 


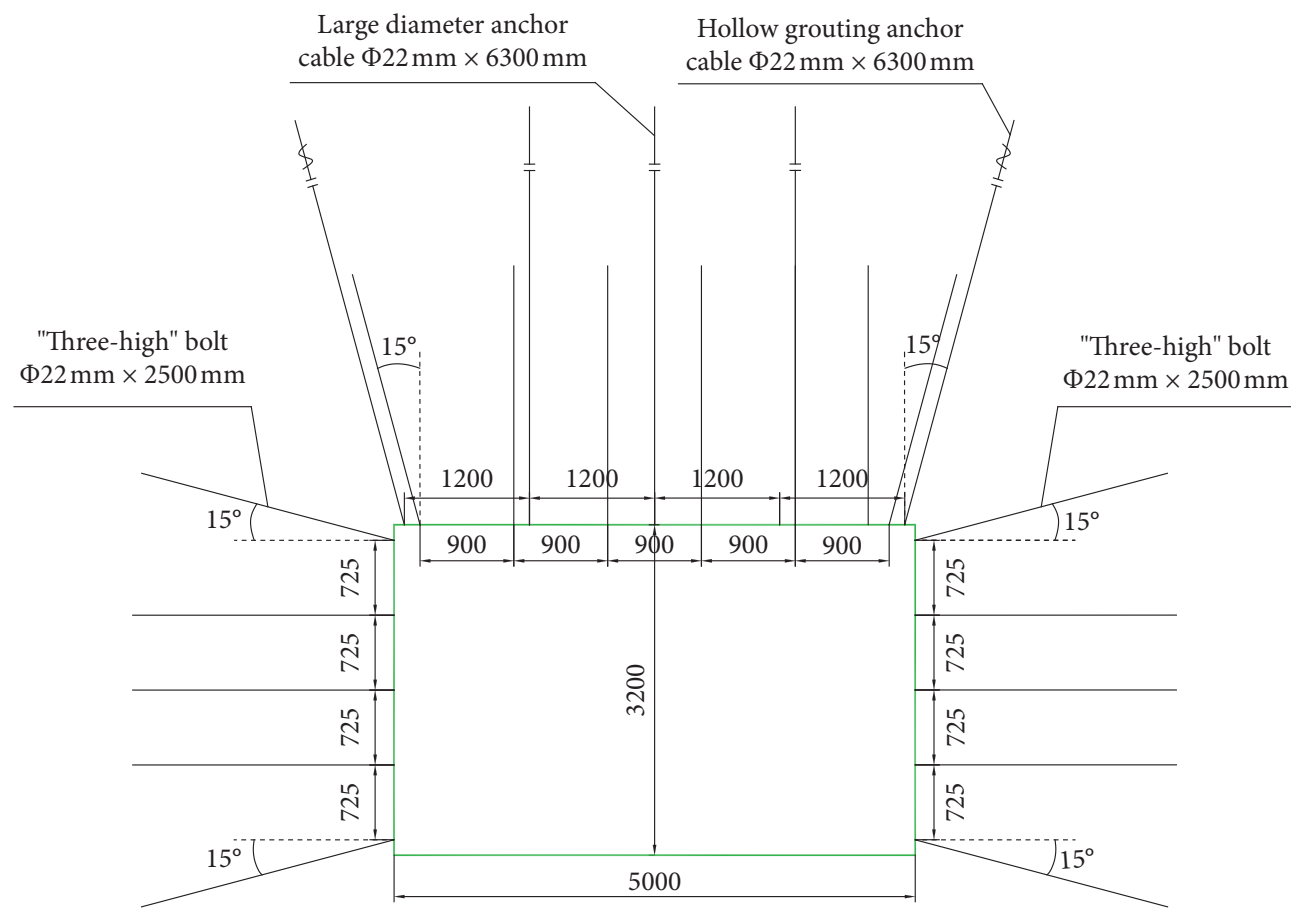

(a)

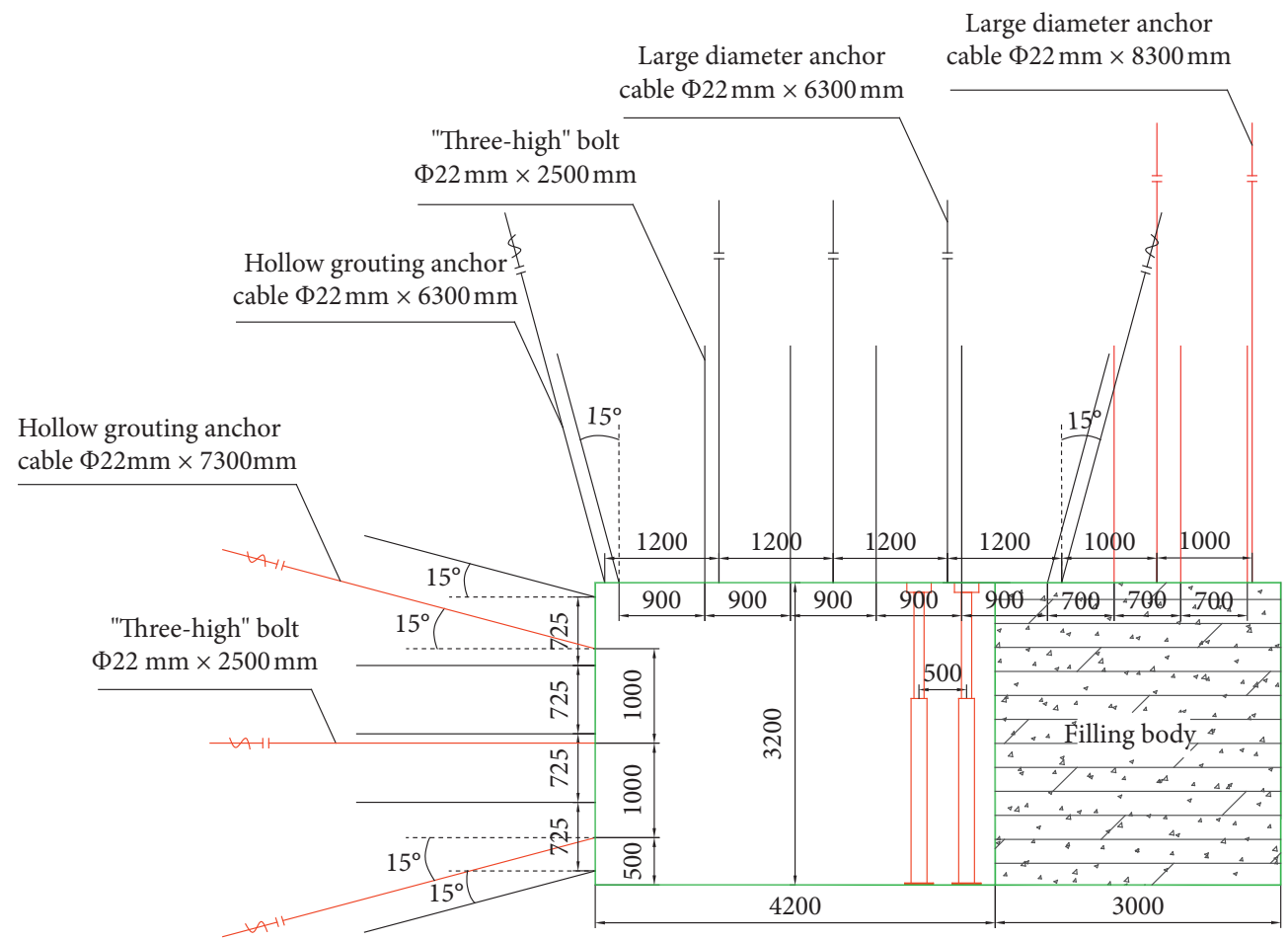

(b)

FIGURE 9: Support scheme of surrounding rock (red represents premining reinforcement). (a) Support parameters of section track roadway (unit: $\mathrm{mm}$ ) and (b) support parameters of gob-side entry retaining (unit: $\mathrm{mm}$ ).

$700 \mathrm{~mm} \times 800 \mathrm{~mm}$. Two large-diameter $\Phi 22 \mathrm{~mm} \times$ L8300 $\mathrm{mm}$ anchor cables were arranged between the two rows of bolts; a preload of $80-100 \mathrm{kN}$ was applied to the cables, and the spacing and row spacing were $1000 \mathrm{~mm} \times 800 \mathrm{~mm}$. In addition, a 10\# galvanized iron wire was used to mechanically weave a $5600 \mathrm{~mm} \times 1000 \mathrm{~mm}$ rhombic mesh.

(4) Bearing Capacity Parameters of Filling Body. Paste concrete was selected as filling material, and its main 


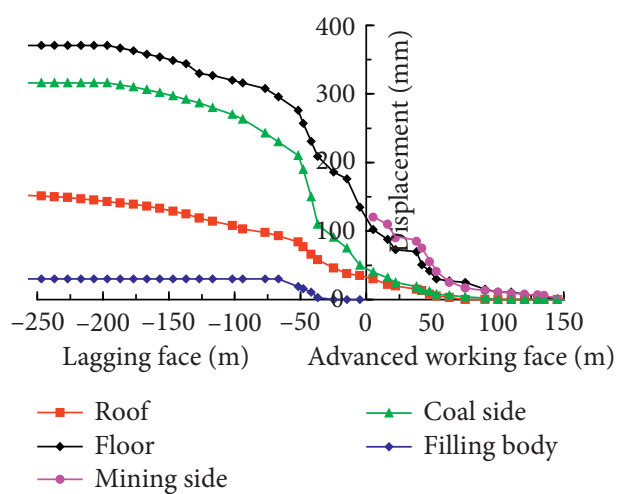

Figure 10: Deformation curves of deep gob-side entry retaining.

components were as follows: paste concrete mixed with silicate, sand, fly ash, and water, as well as additives. The 28-day compressive strength of the concrete was $771-808 \mathrm{kN}$. Before the roadside, threedimensional reinforcing steel bars were preset in the formwork. The reinforcing bars were replaced with $\Phi 22 \mathrm{~mm} \times \mathrm{L} 2500 \mathrm{~mm}$ anchor rods and a $6 \mathrm{~mm}^{2}$ grid reinforcement mesh, which were connected to each other to form a three-dimensional framework.

4.2.3. Effect Analysis. After adopting the above-described scheme, three groups of surface-displacement-measuring stations were installed before and after the gob-side entry retaining in the number 1221 (1) working face to monitor the deformation of the surrounding rock. The deformation curve of the surrounding rock of the gob-side entry retaining is shown in Figure 10.

Under strong dynamic pressure, within $250 \mathrm{~m}$ of the lagging working face, the displacements of the roof, solid coal side, and filling body were $152 \mathrm{~mm}, 316 \mathrm{~mm}$, and $30 \mathrm{~mm}$, respectively, and the amount of floor heave was $371 \mathrm{~mm}$. However, compared with the original support system, the overall deformation of the surrounding rock was controlled effectively, and the roadway section fulfilled the ventilation requirements of the gob-side entry retaining.

\section{Conclusions}

(1) Based on the expansion law of the plastic zone of the surrounding rock, the serious damage area, degree, and scope of damage to the surrounding rock of the gob-side entry retaining in a deep mine under four typical roof conditions were systematically analyzed. The decreasing order of deformation and degree of damage are as follows: the thick immediate roof condition, compound roof condition, thin immediate roof, and thick-hard roof.

(2) Taking a deep gob-side entry retaining with the typical thick-hard roof as an example, a control system for a "multisupport structure" was proposed, including measures to enhance the bearing performance of the anchorage system, improve the strength of the cataclastic coal-rock mass, enhance the bearing capacity of the filling body, and increase the bearing capacity of the tunnel side. The proposed system was applied to the gob-side entry retaining project in the east area of Panyi Mine, where there were no obvious separation and breakage in the deep and shallow strata. The support structure was complete, and it had a good maintenance effect on the surrounding; that is, it fulfilled the ventilation safety and reuse requirements of the gob-side entry retaining in deep mines.

\section{Data Availability}

The data used to support the findings of this study are available from the corresponding author upon request.

\section{Conflicts of Interest}

The authors declare no conflicts of interest.

\section{Acknowledgments}

This research was financially supported by the National Natural Science Foundation of China (nos. 51804129, 51904110, 51904112, and 51904113), the General Program of China Postdoctoral Science Foundation (no. 2020M671301), the Postdoctoral Science Foundation of Jiangsu Province (nos. 2019K139 and 2019Z107), the Open Project of Jiangsu Engineering Laboratory of Assembly Technology of UrbanRural Residential Structure (no. JSZP201902), Industry Education Research Cooperation Projects in Jiangsu Province (no. BY2020007), and Huaishang Talent Plan Program.

\section{References}

[1] S. P. Peng, "Present study and development trend of the deepen coal resource distribution and mining geologic evaluation," Coal, vol. 17, no. 2, pp. 1-11, 2008.

[2] H. Lan, D. K. Chen, and D. B. Mao, "Current status of deep mining and disaster prevention in China," Coal Science and Technology, vol. 44, no. 1, pp. 39-46, 2016.

[3] G. Feng and P. Wang, "Simulation of recovery of upper remnant coal pillar while mining the ultra-close lower panel using long wall top coal caving," International Journal of Mining Science and Technology, vol. 30, no. 1, pp. 55-61, 2020.

[4] H. P. Xie, F. Gao, and Y. Ju, "Research and development of rock mechanics in deep ground engineering," Chinese Journal of Rock Mechanics and Engineering, vol. 34, no. 11, pp. 2161-2178, 2015.

[5] N. Zhang, C. L. Han, J. G. Kan et al., "Theory and practice of surrounding rock control for pillarless gob-side entry retaining," Journal of China Coal Society, vol. 39, no. 8, pp. 1635-1641, 2014.

[6] G. C. Zhang, Z. J. Wen, S. J. Liang et al., "Ground response of a gob-side entry in a longwall panel extracting $17 \mathrm{~m}$-thick coal seam: a case study," Rock Mechanics and Rock Engineering, vol. 53, no. 2, pp. 497-516, 2019.

[7] H. P Kang, L. X. Yan, X. P. Guo et al., "Characteristics of surrounding rock deformation and reinforcement technology of retained entry in working face with multi-entry layout," Chinese Journal of Rock Mechanics and Engineering, vol. 31, no. 10, pp. 2022-2036, 2012. 
[8] Y. L. Tan, F. H. Yu, J. G. Ning, and T. B. Zhao, "Design and construction of entry retaining wall along a gob side under hard roof stratum," International Journal of Rock Mechanics and Mining Sciences, vol. 77, pp. 115-121, 2015.

[9] N. J. Ma, J. Li, Z. Q. Zhao et al., "Distribution of the deviatoric stress field and plastic zone in circular roadway surrounding rock," Journal of China University of Mining \& Technology, vol. 4, no. 2, pp. 206-213, 2015.

[10] W. J. Wang, G. Y. Guo, Y. J. Zhu et al., "Malignant development process of plastic zone and control technology of high stress and soft rock roadway," Journal of China Coal Society, vol. 40, no. 12, pp. 2747-2754, 2015.

[11] H. T. Liu, Z. Hao, X. Y. Wu et al., "Mechanism of blast disaster induced by instantaneous malignant expansion of plastic zone," Journal of China Coal Society, vol. 42, no. 6, pp. 1392-1399, 2017.

[12] H. T. Liu, X. Y. Wu, Z. Hao et al., "Evolution law and stability control of plastic zones of retained entry of working face with double roadways layout," Journal of Mining \& Safety Engineering, vol. 34, no. 4, pp. 689-697, 2017.

[13] S. R. Xie, S. S. Yue, D. D. Chen et al., "Deviatoric stress evolution laws and control of surrounding rock at gob-side entry retaining in deep backfilling mining," Journal of China Coal Society, vol. 43, no. 7, pp. 1837-1846, 2018.

[14] H. S. Jia, G. S. Li, L. Y. Wang et al., "Characteristics of stressfield environment and roof falling mechanism of mining influenced roadway," Journal of Mining \& Safety Engineering, vol. 34, no. 4, pp. 707-714, 2017.

[15] C. Yuan, J. G. Zhang, W. J. Wang et al., "Controlling principles of surrounding rock in soft and broken roadway based on the distribution pattern of plastic zone," Journal of Mining \& Safety Engineering, vol. 37, no. 5, pp. 451-460, 2020.

[16] C. W. Luo, H. B. Li, and Y. Q. Liu, "Characteristics of in-situ stress and variation law of plastic zone of surrounding rocks around deep tunnels in a coal mine," Chinese Journal of Rock Mechanics and Engineering, vol. 30, no. 8, pp. 1613-1618, 2011.

[17] J. Li, B. Peng, and Y. Peng, "A formation mechanism of "low resistance and slight change" in plastic zone of butterfly leaf on the roof in deep roadway," Journal of Mining \& Safety Engineering, vol. 36, no. 03, pp. 465-472, 2019.

[18] X. Y. Wu, H. T. Liu, J. Li et al., "Space-time evolutionary regularity of plastic zone and stability control in repetitive mining roadway," Journal of China Coal Society, vol. 2020, Article ID 8866559, 11 pages, 2020.

[19] Q. B. Meng, L. J. Han, Q. Wang et al., "Optimization analysis of grouting timing in deep and high stress soft rock roadway," Journal of Central South University (Science and Technology), vol. 48, no. 10, pp. 2765-2776, 2017.

[20] J. Hadjigeorgiou and E. Karampinos, "Use of predictive numerical models in exploring new reinforcement options for mining drives," Tunnelling and Underground Space Technology, vol. 67, pp. 27-38, 2017.

[21] F. T. Wang, C. Zhang, S. F. Wei et al., "Whole section anchorgrouting reinforcement technology and its application in underground roadways with loose and fractured surrounding rock," Tunnelling and Underground Space Technology, vol. 51, pp. 133-143, 2016.

[22] G. Z. Yin, J. Lu, D. M. Zhang et al., "Study on plastic zone and permeability-increasing radius of borehole surrounding rock under true triaxial stress conditions," Rock and Soil Mechanics, vol. 40, no. S1, pp. 1-10, 2019.
[23] Z.-H. Wang, H.W. Zhou, C. S. Wang et al., "Stress state and plastic zone of circular tunnel," Journal of Xi'an University of Science and Technology, vol. 37, no. 5, pp. 610-616, 2017.

[24] E. Karampinos, J. Hadjigeorgiou, J. Hazzard, and P. Turcotte, "Discrete element modelling of the buckling phenomenon in deep hard rock mines," International Journal of Rock Mechanics and Mining Sciences, vol. 80, pp. 346-356, 2015.

[25] A.Z. Lu, S. J. Wang, X. L. Zhang, and N. Zhang, "Solution of the elasto-plastic interface of circular tunnels in Hoek-Brown media subjected to non-hydrostatic stress," International Journal of Rock Mechanics and Mining Sciences, vol. 106, pp. 124-132, 2018.

[26] M. R. Zareifard and A. Fahimifar, "Analytical solutions for the stresses and deformations of deep tunnels in an elastic-brittleplastic rock mass considering the damaged zone," Tunnelling and Underground Space Technology, vol. 58, pp. 186-196, 2016. 